\title{
Effect of chemical composition on the electrical conductivity of gneiss at high temperatures and pressures
}

\author{
Lidong Dai ${ }^{1}$, Wenqing Sun ${ }^{1,2}$, Heping $\mathrm{Li}^{1}$, Haiying $\mathrm{Hu}^{1}$, Lei $\mathrm{Wu}^{1}$, and Jianjun Jiang ${ }^{1}$ \\ ${ }^{1}$ Key Laboratory of High-Temperature and High-Pressure Study of the Earth's Interior, Institute of Geochemistry, \\ Chinese Academy of Sciences, Guiyang, 550081, China \\ ${ }^{2}$ University of Chinese Academy of Sciences, Beijing, 100049, China
}

Correspondence: Lidong Dai (dailidong@vip.gyig.ac.cn)

Received: 31 August 2017 - Discussion started: 27 September 2017

Revised: 5 February 2018 - Accepted: 11 February 2018 - Published: 6 March 2018

\begin{abstract}
The electrical conductivity of gneiss samples with different chemical compositions $\left(W_{A}=\right.$ $\mathrm{Na}_{2} \mathrm{O}+\mathrm{K}_{2} \mathrm{O}+\mathrm{CaO}=7.12, \quad 7.27$ and $7.64 \%$ weight percent) was measured using a complex impedance spectroscopic technique at $623-1073 \mathrm{~K}$ and $1.5 \mathrm{GPa}$ and a frequency range of $10^{-1}$ to $10^{6} \mathrm{~Hz}$. Simultaneously, a pressure effect on the electrical conductivity was also determined for the $W_{A}=7.12 \%$ gneiss. The results indicated that the gneiss conductivities markedly increase with total alkali and calcium ion content. The sample conductivity and temperature conform to an Arrhenius relationship within a certain temperature range. The influence of pressure on gneiss conductivity is weaker than temperature, although conductivity still increases with pressure. According to various ranges of activation enthalpy (0.35-0.52 and 0.76$0.87 \mathrm{eV}$ ) at $1.5 \mathrm{GPa}$, two main conduction mechanisms are suggested that dominate the electrical conductivity of gneiss: impurity conduction in the lower-temperature region and ionic conduction (charge carriers are $\mathrm{K}^{+}, \mathrm{Na}^{+}$ and $\mathrm{Ca}^{2+}$ ) in the higher-temperature region. The electrical conductivity of gneiss with various chemical compositions cannot be used to interpret the high conductivity anomalies in the Dabie-Sulu ultrahigh-pressure metamorphic belt. However, the conductivity-depth profiles for gneiss may provide an important constraint on the interpretation of field magnetotelluric conductivity results in the regional metamorphic belt.
\end{abstract}

\section{Introduction}

According to magnetotelluric (MT) and geomagnetic depthsounding results, the electrical conductivity of geological samples at high temperature and pressure can be used to extrapolate the mineralogical composition and thermodynamic state in the Earth's interior (Maumus et al., 2005; Dai et al., 2008; Hui et al., 2015; Manthilake et al., 2015; Li et al., 2016; $\mathrm{Hu}$ et al., 2017). High conductivity anomalies are widely distributed in the middle to lower crust and upper mantle, and there are various causes of these anomalies in different regions (Xiao et al., 2007, 2011; Pape et al., 2015; Novella et al., 2017). Hence, it is crucial to comprehensively measure the electrical conductivities of minerals and rocks that are distributed in the deep Earth. A series of electrical conductivity results of the main minerals and rocks have been reported in previous studies under high temperature and pressure conditions (Fuji-ta et al., 2007; Hu et al., 2011, 2013; Dai et al., 2012; Yang et al., 2012; Sun et al., 2017a). However, the electrical conductivity of most metamorphic rocks has not been explored at high temperature and pressure, and thus the interpretation of high conductivity anomalies distributed in representative regional metamorphic belts is still not comprehensive.

A regional metamorphic ultrahigh-pressure belt for the Dabie-Sulu orogen is a complexly giant geotectonic unit in central-eastern China. Geophysical exploration results confirmed that a large number of high conductivity anomalies have been observed in metamorphic belts (Xiao et al., 2007; Wannamaker et al., 2009; Zeng et al., 2015). Metamorphic rocks (e.g., slate, schist, gneiss, granulite and eclogite) with different degrees of metamorphism play an important role 
because of their widespread distribution in regional metamorphic belts. Dai et al. (2016) measured the electrical conductivity of dry eclogite at 873-1173 K, 1.0-3.0 GPa and different oxygen partial pressures (using $\mathrm{Cu}+\mathrm{CuO}, \mathrm{Ni}+\mathrm{NiO}$ and $\mathrm{Mo}+\mathrm{MoO}_{2}$ solid oxygen buffers) and found that the hopping of small polaron is the dominant conduction mechanism for dry eclogite at high temperature and pressure. The electrical conductivity of natural eclogite is much lower than the high conductivity anomaly in the Dabie-Sulu ultrahighpressure metamorphic (UHPM) belt of eastern China. Granulite is another important metamorphic rock distributed in a majority of regional metamorphic belts. The electrical conductivity of granulite is lowered by repetitive heating cycles with a conductivity range of about $10^{-7}-10^{-2} \mathrm{~S} \mathrm{~m}^{-1}$ at $1.0 \mathrm{GPa}$ and up to about $900 \mathrm{~K}$ (Fuji-ta et al., 2004). Due to the complicated mineralogical assemblage of granulite and rock structure, the features of the electrical conductivity values over heating cycles have not been explained and the conduction mechanism for granulite not definitively stated. Gneiss is formed at middle- to lower-crustal pressure and temperature conditions and widely distributed in regional metamorphic belts. The main rock-forming minerals of gneiss are feldspar, quartz and biotite. The electrical conductivity of gneiss increases with temperature, and the conductivity values range from about $10^{-4}-10^{-2} \mathrm{~S} \mathrm{~m}^{-1}$ at up to $1000 \mathrm{~K}$ and $1.0 \mathrm{GPa}$ (Fuji-ta et al., 2007). On the basis of the dominant rock-bearing mineralogical assembly of the metamorphic rock, gneiss can generally be divided into types, such as plagioclase gneiss, quartz gneiss and biotite gneiss. Therefore, it is crucial to investigate the electrical conductivity of gneisses with various chemical compositions and mineralogical constituents. The electrical conductivity of granite dramatically increases with alkaline and calcium ion content at $623-1173 \mathrm{~K}$ and $0.5-1.5 \mathrm{GPa}$ (Dai et al., 2014). Impurity conduction has been proposed to be the dominant conduction mechanism for granite in the lower-temperature region, and alkaline ions, including $\mathrm{K}^{+}, \mathrm{Na}^{+}$and $\mathrm{Ca}^{2+}$, are probable charge carriers at higher temperatures.

In the present study, we measured the electrical conductivity of gneiss samples in situ under $0.5-2.0 \mathrm{GPa}, 623-1073 \mathrm{~K}$ and three different chemical compositions. The influences of temperature, pressure and chemical composition on the gneiss electrical conductivity were determined, and the dominant conduction mechanism for gneiss is discussed in detail. On the basis of the conductivity results, the geophysical implications for the high conductivity anomalies of the DabieSulu UHPM belt were explored in depth.
Table 1. Mineralogical assemblage of three natural gneiss samples. Pl: plagioclase, Qz: quartz and Bi: biotite.

\begin{tabular}{ll}
\hline Run no. & Mineralogical associations \\
\hline DS12 & Pl $(50 \%)+\mathrm{Qz}(40 \%)+\mathrm{Bi}(10 \%)$ \\
DS13 & Pl $(25 \%)+\mathrm{Qz}(40 \%)+\mathrm{Bi}(35 \%)$ \\
DS14 & Pl $(60 \%)+\mathrm{Qz}(25 \%)+\mathrm{Bi}(15 \%)$ \\
\hline
\end{tabular}

\section{Experimental procedures}

\subsection{Sample preparation}

Three relatively homogeneous natural gneiss samples with parallel to foliation direction were collected from Xinjiang, China. The sample surfaces were fresh, non-fractured and non-oxidized, without evidence of alteration before and after the experiments. To determine the gneiss mineralogical assemblage, we used optical microscopy and scanning electron microscopy (SEM) at the State Key Laboratory of Ore Deposit Geochemistry, Institute of Geochemistry, Chinese Academy of Sciences, Guiyang, China. The major elemental content of the gneiss samples was analyzed by X-ray fluorescence spectrometry (XRF) at Australian Laboratory Services, Shanghai, China. The main rock-forming minerals of three gneiss samples were feldspar, quartz and biotite (Fig. 1). The volume percentage varied for each corresponding rock-forming mineral in different gneiss samples (Table 1). Three gneiss samples had the same mineralogical assemblage, and all of them belong to the biotite-bearing felsic gneiss. Table 2 shows the results of whole rock analysis by XRF for the three gneiss samples. We found that the total alkali, such as $\mathrm{K}^{+}$and $\mathrm{Na}^{+}$, and the divalent cationic calcium metal ion content varied for each sample (Table 2).

\subsection{Impedance measurements}

High temperatures and pressures for the experiments were generated in a YJ-3000t multi-anvil apparatus, and the impedance spectra were collected using a Solartron-1260 impedance-gain-phase analyzer at the Key Laboratory of High-Temperature and High-Pressure Study of the Earth's Interior, Institute of Geochemistry, Chinese Academy of Sciences, Guiyang, China. All components of the experimental assemblage (ceramic tubes, pyrophyllite, $\mathrm{Al}_{2} \mathrm{O}_{3}$ and $\mathrm{MgO}$ sleeves) were previously baked at $1073 \mathrm{~K}$ for $12 \mathrm{~h}$ in a muffle furnace to avoid the influence of absorbed water on the electrical conductivity measurements. The sample was then loaded into an $\mathrm{MgO}$ insulation tube (Fig. 2). Two nickel disks $(6.0 \mathrm{~mm}$ in diameter and $0.5 \mathrm{~mm}$ in thickness) were applied to the top and bottom of the sample to act as electrodes. To shield against external electromagnetic and spurious signal interference, a layer of nickel foil with a thickness of $0.025 \mathrm{~mm}$ was installed between the alumina and magnesia sleeves. These sleeves have good insulating properties for 


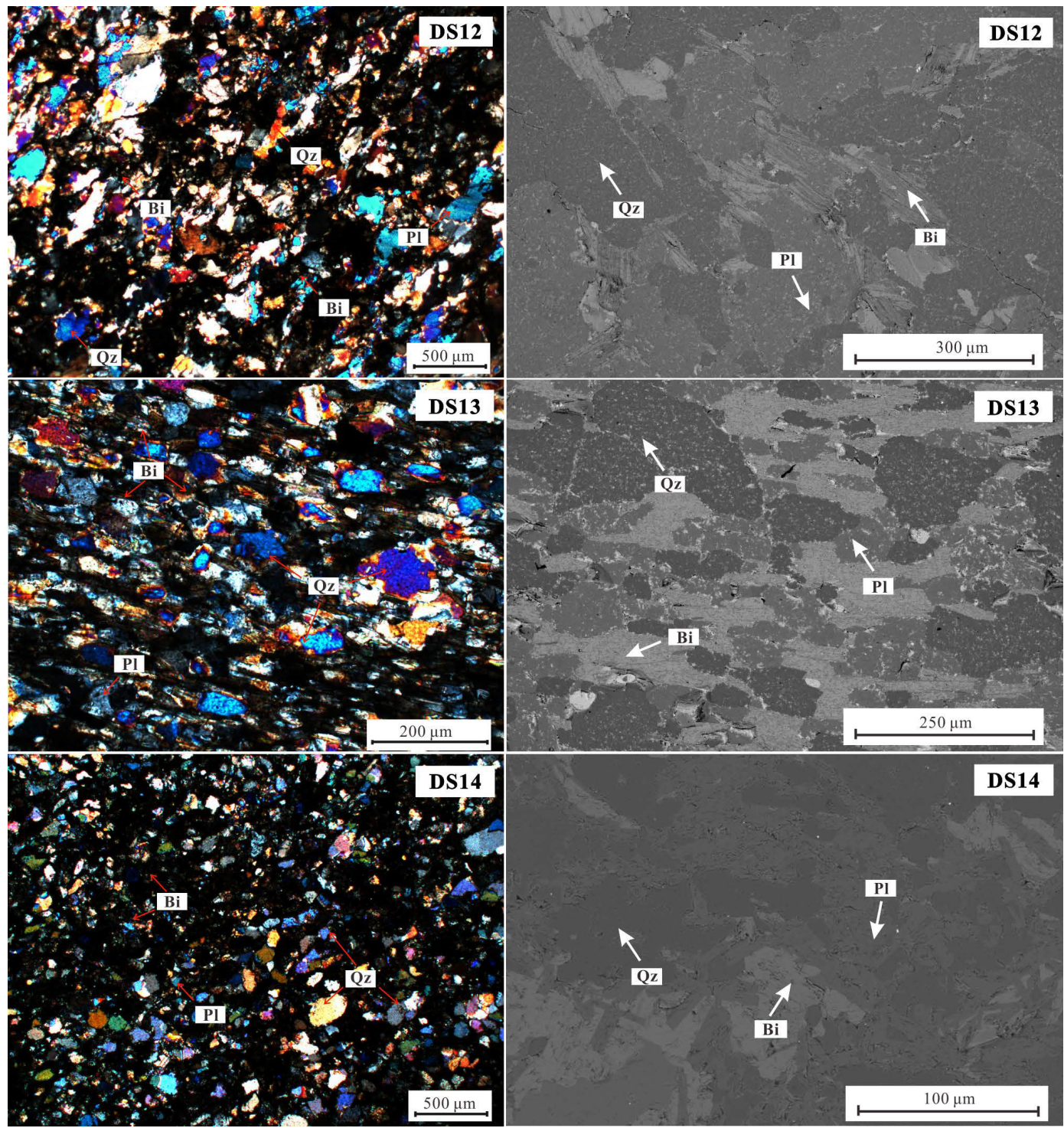

Figure 1. Photomicrographs and electron backscattered images of three natural gneiss samples under the polarizing microscope. Pl: plagioclase, Qtz: quartz and Bt: biotite.

current and transmitting pressure. A pyrophyllite cube (edge length: $32.5 \mathrm{~mm}$ ) was used as the pressure medium, and the heater was composed of three-layer stainless steel sheets with a total thickness of $0.5 \mathrm{~mm}$. The sample assembly was placed in an oven at $330 \mathrm{~K}$ to keep it dry before the experiment.

In the experiments, the pressure was slowly increased to the desired value at a rate of $1.0 \mathrm{GPah}^{-1}$, and then the temperature was increased at a rate of $300 \mathrm{~K} \mathrm{~h}^{-1}$ to the designated values. The Solartron-1260 impedance-gain-phase analyzer with an applied voltage of $3 \mathrm{~V}$ and frequency range of $10^{-1}-10^{6} \mathrm{~Hz}$ was used to collect impedance spectra when the pressure and temperature were stable. At the desired pressure, the spectra were measured at a certain temperature, which was changed in $50 \mathrm{~K}$ intervals. The impedance spectra of gneiss samples with $W_{A}\left(\mathrm{Na}_{2} \mathrm{O}+\mathrm{K}_{2} \mathrm{O}+\mathrm{CaO}\right)=7.12 \%$ were collected under conditions of $0.5-2.0 \mathrm{GPa}$ and $623-$ $1073 \mathrm{~K}$. The spectra of the other two gneiss samples $\left(W_{A}=7.27\right.$ and $\left.7.64 \%\right)$ were measured at $623-1073 \mathrm{~K}$ and $1.5 \mathrm{GPa}$. To confirm the data reproducibility, we measured the electrical conductivity of gneiss over two heating and cooling cycles at a constant pressure. The errors of temperature and pressure were $\pm 5 \mathrm{~K}$ and $\pm 0.1 \mathrm{GPa}$, respectively.

\section{Results}

The typical complex impedance spectra for the run DS12 gneiss samples at $1.5 \mathrm{GPa}$ and $623-1073 \mathrm{~K}$ are shown in Fig. 3. All of these obtained spectra are composed of an almost ideal semicircle in the high-frequency domain and an 
Table 2. Chemical composition of whole rock analysis by X-ray fluorescence (XRF) for three gneiss samples.

\begin{tabular}{lrrr}
\hline Oxides (wt \%) & DS12 & DS13 & DS14 \\
\hline $\mathrm{SiO}_{2}$ & 64.40 & 68.59 & 69.87 \\
$\mathrm{Al}_{2} \mathrm{O}_{3}$ & 15.30 & 13.62 & 14.88 \\
$\mathrm{MgO}$ & 3.15 & 3.00 & 1.78 \\
$\mathrm{CaO}$ & 1.61 & 2.48 & 0.52 \\
$\mathrm{Na}{ }_{2} \mathrm{O}$ & 2.27 & 2.46 & 2.26 \\
$\mathrm{~K}_{2} \mathrm{O}$ & 3.24 & 2.33 & 4.86 \\
$\mathrm{Fe}_{2} \mathrm{O}_{3}$ & 6.28 & 5.57 & 3.37 \\
$\mathrm{TiO}_{2}$ & 0.81 & 0.61 & 0.38 \\
$\mathrm{Cr}_{2} \mathrm{O}_{3}$ & 0.02 & 0.02 & 0.01 \\
$\mathrm{MnO}_{\mathrm{BaO}}$ & 0.08 & 0.07 & 0.03 \\
$\mathrm{SrO}_{\mathrm{P} O} \mathrm{O}_{5}$ & 0.06 & 0.02 & 0.12 \\
$\mathrm{SO}_{3}$ & 0.03 & 0.03 & 0.02 \\
$\mathrm{LOI}$ & 0.19 & 0.16 & 0.08 \\
$\mathrm{Total}$ & 1.0 .01 & $<0.01$ & 0.28 \\
\hline
\end{tabular}

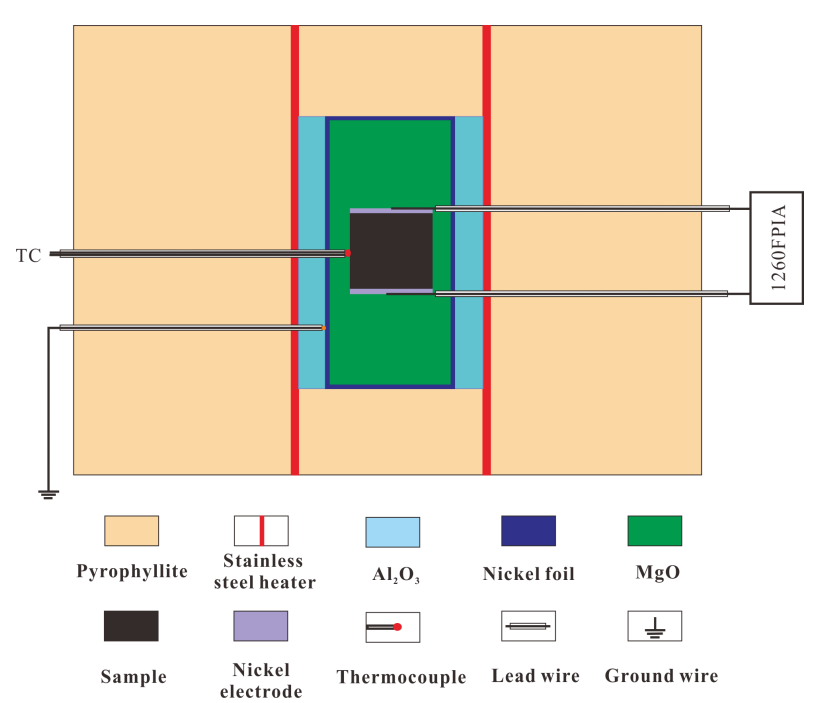

Figure 2. Experimental setup for electrical conductivity measurements at high temperatures and pressures.

additional tail in the lower-frequency domain. Other complex impedance spectra of the gneiss samples at other pressures displayed the same characteristics as those shown in Fig. 3. Figure 4 displays the real and imaginary parts of complex impedance for the runs DS13 and DS14 gneiss samples as a function of the measured frequency at $1.5 \mathrm{GPa}$ and $623-1073 \mathrm{~K}$. The real part values almost remain unchanged over a frequency range of $10^{6}-10^{4} \mathrm{~Hz}$ and sharply increased at $10^{4}-10^{2} \mathrm{~Hz}$; these values then slowly increased within the $10^{2}$ to $10^{-1} \mathrm{~Hz}$ lower-frequency region. The values of imaginary parts almost remain unchanged within a frequency range of $10^{6}-10^{5} \mathrm{~Hz}$, and the values gradually increased at $10^{5}-10^{3} \mathrm{~Hz}$ and decreased at $10^{3}-10^{1} \mathrm{~Hz}$; these values then

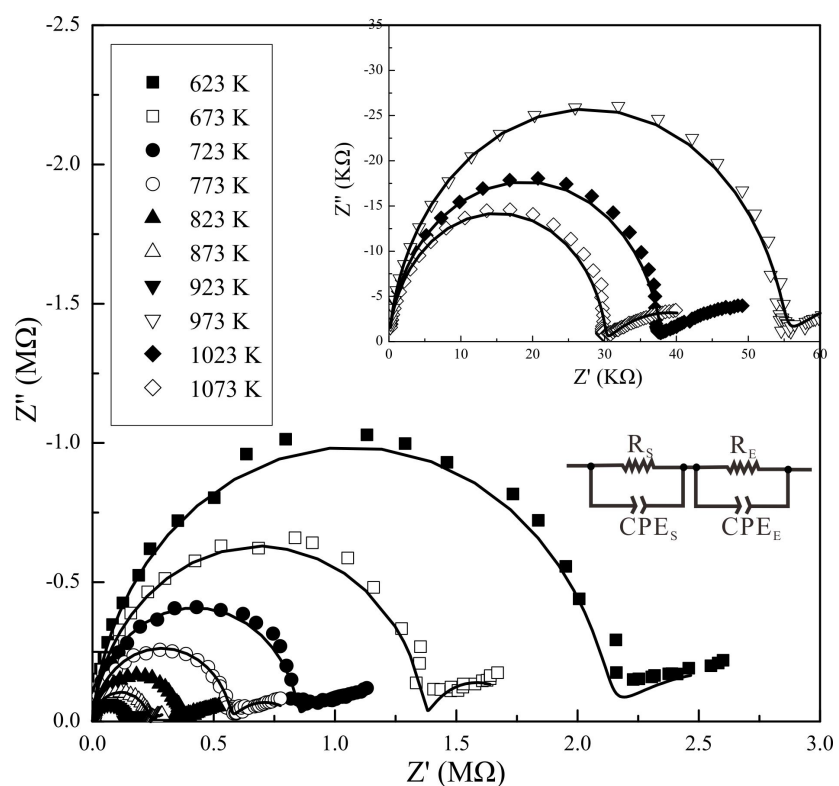

Figure 3. Representative complex impedance spectra for run DS12 gneiss under conditions of $1.5 \mathrm{GPa}$ and $623-1073 \mathrm{~K}$.

slowly increased in the $10^{1}$ to $10^{-1} \mathrm{~Hz}$ lower-frequency region. Roberts and Tyburczy (1991) and Saltas et al. (2013) have suggested that the ideal semicircle represents the bulk electrical properties of a sample, and the additional tail is characteristic of diffusion processes at the sample-electrode interface. Hence, the bulk sample resistance can be obtained by fitting the ideal semicircle in the high-frequency domain. A series connection of resistance and constant phase elements $\left(R_{\mathrm{S}}-\mathrm{CPE}_{\mathrm{S}}\right)$ and the interaction of charge carriers with the electrode $\left(R_{\mathrm{E}}-\mathrm{CPE}_{\mathrm{E}}\right)$ was applied to be the equivalent circuit. All fitting errors of the electrical resistance were less than $5 \%$. Based on the sample size and electrical resistance, the electrical conductivity of the sample was calculated with

$\sigma=L / S R$

where $L$ is the height of the sample (m), $S$ is the crosssectional area of the electrodes $\left(\mathrm{m}^{2}\right), R$ is the fitting resistance $(\Omega)$ and $\sigma$ is the electrical conductivity of the sample $\left(\mathrm{S} \mathrm{m}^{-1}\right)$.

The logarithmic electrical conductivities of the gneiss samples were plotted against the reciprocal temperatures under conditions of $623-1073 \mathrm{~K}$ and $0.5-2.0 \mathrm{GPa}$. The electrical conductivities of gneiss with $X_{A}=7.12 \%$ were measured in two sequential heating and cooling cycles at $1.5 \mathrm{GPa}$ (Fig. 5). After the first heating cycle, the electrical conductivities of the gneiss at the same temperature were close to each other in other cycles. We confirmed that our experimental data were reproducible, and the gneiss sample was kept at a steady state after the first heating cycle. Two different linear relationships of logarithmic electrical conductivity and 
reciprocal temperature were separated by an inflection point. The electrical conductivity of gneiss with $W_{A}=7.12 \%$ significantly increased with temperatures above $723 \mathrm{~K}$ at $0.5-$ $1.0 \mathrm{GPa}$, and this phenomenon occurred after $773 \mathrm{~K}$ at $1.5-$ $2.5 \mathrm{GPa}$ (Fig. 6). The electrical conductivity of the samples increased with pressure, but the effect of pressure on conductivity was weaker than temperature. For other gneiss samples $\left(W_{A}=7.27\right.$ and $\left.7.64 \%\right)$, the inflection points appeared at $773 \mathrm{~K}$ under all designated pressures (Fig. 7). In a specific temperature range, the relationship between electrical conductivity and temperature fits the Arrhenius formula:

$\sigma=\sigma_{0} \exp (-\Delta H / k T)$,

$\Delta H=\Delta U+P \Delta V$,

where $\sigma_{0}$ is the pre-exponential factor $\left(\mathrm{S} \mathrm{m}^{-1}\right), \Delta H$ is the activation enthalpy $(\mathrm{eV}), k$ is the Boltzmann constant $\left(\mathrm{eV} \mathrm{K}^{-1}\right)$, $T$ is the absolute temperature (K), $\Delta U$ is the activation energy $(\mathrm{eV}), P$ is the pressure $(\mathrm{GPa})$ and $\Delta V$ is the activation volume $\left(\mathrm{cm}^{3} \mathrm{~mole}^{-1}\right)$. All fitting parameters for the electrical conductivities of three gneiss samples are listed in Table 3. The activation enthalpy values $(\Delta H)$ for the gneiss samples are $0.35-0.58 \mathrm{eV}$ in the lower-temperature region and $0.71-$ $1.05 \mathrm{eV}$ in the higher-temperature region, respectively. In addition, the logarithms of pre-exponential factor values ( $\log$ $\sigma_{0}$ ) were transformed from negative to positive from the correspondent lower to the higher temperature ranges.

The total alkali and calcium ion content of $\mathrm{K}_{2} \mathrm{O}, \mathrm{Na}_{2} \mathrm{O}$ and $\mathrm{CaO}$ is a remarkable influence on the electrical conductivities of the gneiss samples. As shown in Fig. 7, the electrical conductivity of the gneiss samples increased with the total weight percent of $\mathrm{K}_{2} \mathrm{O}, \mathrm{Na}_{2} \mathrm{O}$ and $\mathrm{CaO}$. This reflects the fact the electrical conductivity of the gneiss samples is controlled mainly by minerals that contain abundant $\mathrm{K}_{2} \mathrm{O}, \mathrm{Na}_{2} \mathrm{O}$ and $\mathrm{CaO}$. The cations of feldspar are $\mathrm{K}^{+}, \mathrm{Na}^{+}$and $\mathrm{Ca}^{2+}$, and $\mathrm{K}^{+}$is also the main cation of biotite. Furthermore, impurity ions $\left(\mathrm{K}^{+}, \mathrm{Na}^{+}\right.$and $\left.\mathrm{Al}^{3+}\right)$ have been suggested to be the charge carriers for quartz samples (Wang et al., 2010). In addition, the electrical conductivity of the gneiss samples does not regularly change with variations in biotite-bearing content (Fig. 7 and Table 1). Based on all of the experimental results, the biotite content is not the main influential factor on the electrical conductivity of gneiss. Therefore, we cannot distinguish the specific mineral that controls the electrical conductivity of the gneiss samples. However, it was reasonable to consider the gneiss sample as a complex whole and analyze the electrical conductivity of gneiss with various chemical compositions at high temperature and pressure.

\section{Discussion}

\subsection{A comparison with previous studies}

As three constituent minerals of gneiss, feldspar, biotite and quartz dominated the electrical conductivity of the whole rock at high temperature and pressure. Due to their sophisticated mineralogical assemblage and rock structure, the gneiss samples were unstable in the first heating cycle. In this process, the impurity ions may have been distributed, the grain size slightly changed and the microfractures gradually closed. After the first cycle, the electrical conductivity of the gneiss samples had good repeatability. This suggested that the gneiss samples were in a stable state. The electrical conductivity range of the gneiss samples with various chemical compositions was about $10^{-5}-10^{-1} \mathrm{~S} \mathrm{~m}^{-1}$ at $623-973 \mathrm{~K}$ and $0.5-2.0 \mathrm{GPa}$. The electrical conductivity was slightly related to pressure and conforms to previous conclusions that the influence of pressure on mineral and rock conductivity is much weaker than temperature (Xu et al., 2000; Hu et al., 2011; Dai and Karato, 2014a, b). The possible reason is that the effect of pressure on the activity of the charge carriers is weaker than temperature. The total alkaline ion content of $\mathrm{K}_{2} \mathrm{O}, \mathrm{Na}_{2} \mathrm{O}$ and $\mathrm{CaO}$ has a crucial influence on the electrical conductivity of gneiss. Previous studies have investigated the electrical conductivity of minerals and rocks with various chemical compositions, and the conclusions were similar to ours (Dai et al., 2014). Fiji-ta et al. (2007) performed the electrical conductivity of gneiss perpendicular and parallel to foliation at up to $1000 \mathrm{~K}$ and a constant pressure of $1.0 \mathrm{GPa}$. The conductivity of gneiss measured perpendicular to foliation was 1 order of magnitude lower than the value measured parallel to foliation. However, the influence of pressure and chemical composition on the electrical conductivity of gneiss has not been studied. In the present work, we investigated the electrical conductivity of gneiss parallel to foliation. As shown in Fig. 8, the electrical conductivity of gneiss from Fuji-ta et al. (2007) was higher than our results in the lower temperature range, and values were lower than the conductivity of gneiss with $W_{A}=7.27$ and $7.64 \%$ in this study. This discrepancy is probably caused by varying chemical compositions of the gneiss samples. Dai et al. (2014) measured the electrical conductivity of granite at $0.5-1.5 \mathrm{GPa}$ and $623-1173 \mathrm{~K}$, and the main rock-forming minerals were also quartz, feldspar, and biotite. They found that the content of calcium and alkali ions significantly affected the electrical conductivity of granite under conditions of high temperature and high pressure. Electrical conductivities of granite and gneiss increased with calcium and alkali ion content. However, the electrical conductivity of granite was much lower than gneiss (Fig. 8). This difference may be caused by the various chemical compositions and rock structures between granite and gneiss. Feldspars are the main constituent rock-forming minerals in gneiss, and thus it is important to compare the electrical conductivity of feldspar. The electri- 
Table 3. Fitted parameters of the Arrhenius relation for the electrical conductivity of three gneiss samples. Two equations, $\sigma=$ $\sigma_{0} \exp (-\Delta H / k T)$ and $\Delta H=\Delta U+P \Delta V$, are adopted in which $\sigma_{0}$ is the pre-exponential factor $\left(\mathrm{S} \mathrm{m}^{-1}\right), \Delta H$ is the activation enthalpy $(\mathrm{eV}), k$ is the Boltzmann constant $\left(\mathrm{eV} \mathrm{K}^{-1}\right), T$ is the absolute temperature $(\mathrm{K}), \Delta U$ is the activation energy $(\mathrm{eV}), P$ is the pressure $(\mathrm{GPa})$ and $\Delta V$ is the activation volume $\left(\mathrm{cm}^{3} \mathrm{~mole}^{-1}\right)$. The symbol $R^{2}$ is denoted as the fitted correlation coefficient.

\begin{tabular}{lrrrrrrr}
\hline Run no. & $P(\mathrm{GPa})$ & $T(\mathrm{~K})$ & $\log \sigma_{0}\left(\mathrm{~S} \mathrm{~m}^{-1}\right)$ & $\Delta H(\mathrm{eV})$ & $R^{2}$ & $\Delta U(\mathrm{eV})$ & $\Delta V\left(\mathrm{~cm}^{3} \mathrm{~mole}^{-1}\right)$ \\
\hline DS12 & 0.5 & $623-723$ & $-0.20 \pm 0.09$ & $0.58 \pm 0.01$ & 99.91 & $0.63 \pm 0.01$ & $-7.10 \pm 0.92$ \\
& 1.0 & $623-723$ & $-0.06 \pm 0.01$ & $0.56 \pm 0.01$ & 99.99 & & \\
& 1.5 & $623-773$ & $-0.06 \pm 0.02$ & $0.52 \pm 0.02$ & 99.66 & & \\
& 2.0 & $623-773$ & $-0.38 \pm 0.05$ & $0.47 \pm 0.01$ & 99.96 & & $-2.69 \pm 2.40$ \\
& 0.5 & $773-1073$ & $1.11 \pm 0.08$ & $0.77 \pm 0.01$ & 99.79 & $0.78 \pm 0.03$ & \\
DS13 & 1.0 & $773-1073$ & $0.98 \pm 0.08$ & $0.72 \pm 0.01$ & 99.77 & & \\
& 1.5 & $823-1073$ & $1.43 \pm 0.05$ & $0.76 \pm 0.01$ & 99.93 & & \\
DS14 & 2.0 & $823-1073$ & $1.26 \pm 0.11$ & $0.71 \pm 0.03$ & 99.51 & & \\
& 1.5 & $623-773$ & $-0.92 \pm 0.04$ & $0.35 \pm 0.01$ & 99.93 & & \\
& 1.5 & $823-1073$ & $2.26 \pm 0.12$ & $0.84 \pm 0.01$ & 99.66 & & \\
& & $823-773$ & $-0.49 \pm 0.10$ & $0.38 \pm 0.01$ & 99.60 & & \\
\end{tabular}
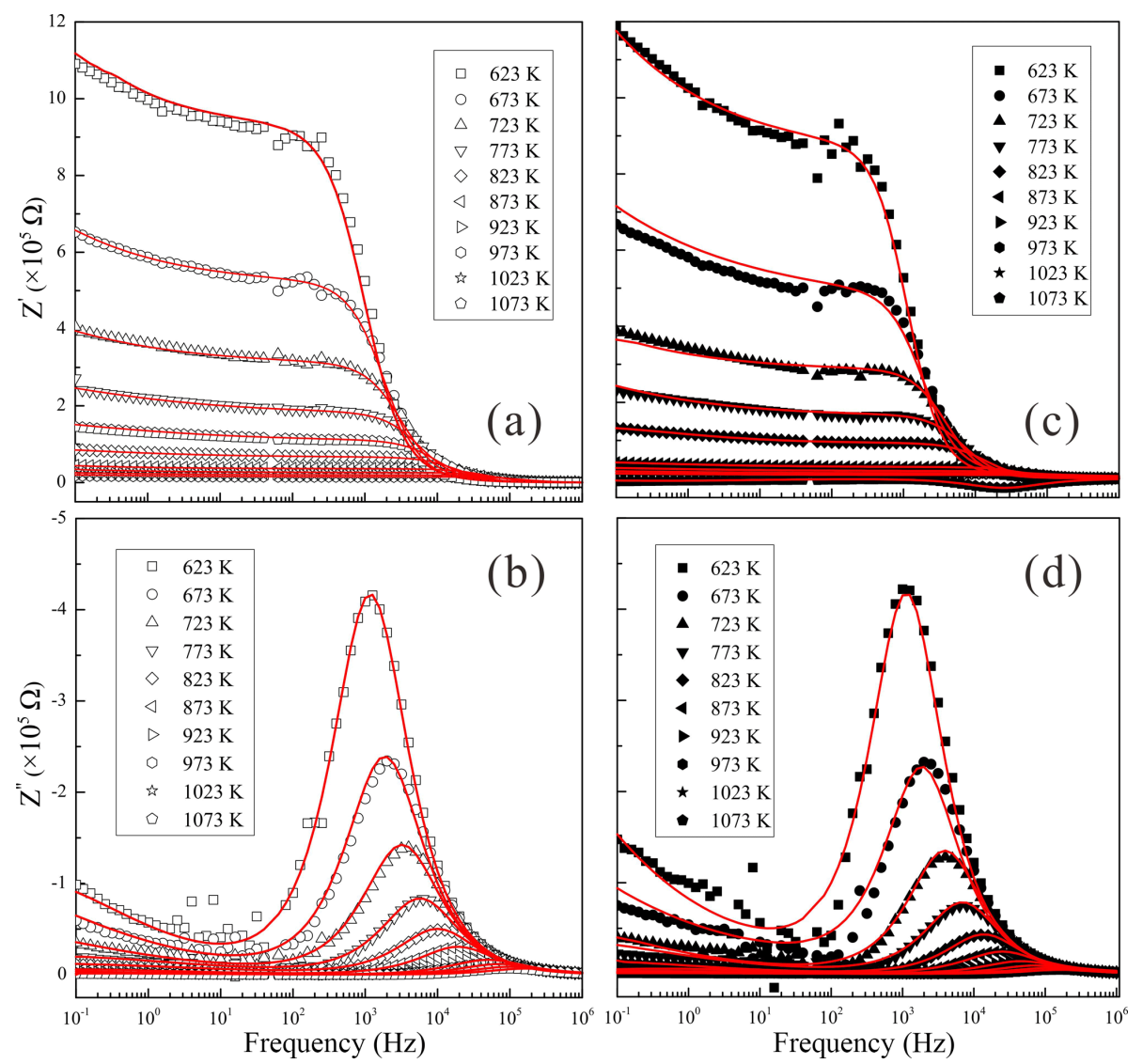

Figure 4. Real and imaginary parts of complex impedance as functions of the measured frequencies for the runs DS13 and DS14 gneiss samples under conditions of $1.5 \mathrm{GPa}$ and 623-1073 K. (a) real and (b) imaginary parts for the run DS13 gneiss; (c) Real and (d) imaginary parts for the run DS14 gneiss.

cal conductivity of $\mathrm{K}$-feldspar is 1 order of magnitude lower than albite, and $\mathrm{K}^{+}$and $\mathrm{Na}^{+}$ions are the charge carriers of $\mathrm{K}$ feldspar and albite, respectively (Hu et al., 2013). As shown in Fig. 8, the electrical conductivity of alkali feldspar is much higher than the gneiss samples. This may be because the concentration of alkali ions in feldspar is higher than gneiss. In 


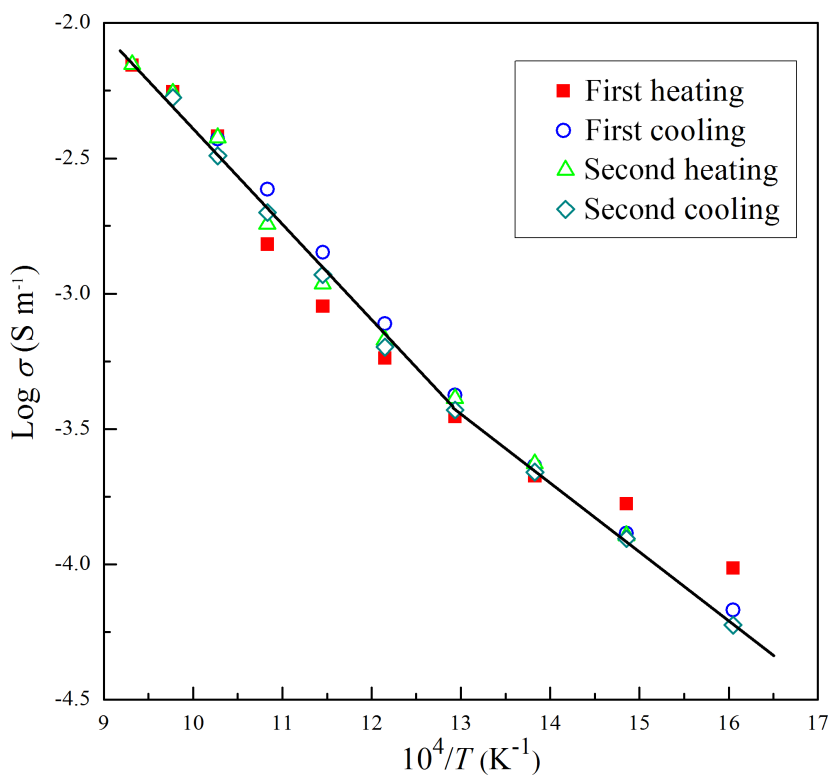

Figure 5. Logarithm of the electrical conductivities versus the reciprocal temperatures for run DS12 gneiss during two heating and cooling cycles at $1.5 \mathrm{GPa}$.

addition, granulite is another significant metamorphic rock and usually coexists with gneiss. The electrical conductivity of granulite is moderately higher than gneiss. The electrical conductivity of quartz at $1.0 \mathrm{GPa}$ is slightly lower than gneiss with $X_{A}=7.27 \%$ at $1.5 \mathrm{GPa}$, and the slope of the linear relationship between the logarithm of electrical conductivity and the reciprocal of temperature for quartz is close to gneiss in a lower temperature range (Wang et al., 2010). The conductivity of phlogopite is higher than gneiss with $X_{A}=7.64 \%$ at higher temperatures $(>773 \mathrm{~K})$ and lower than gneiss samples at lower temperatures $(<773 \mathrm{~K})$. Furthermore, the slope of the linear relationship between the logarithm of electrical conductivity for the phlogopite and the reciprocal temperature is much higher than the slope of the gneiss samples ( $\mathrm{Li}$ et al., 2016). Compared with Ferri et al. (2013), the electrical conductivity of the garnet-biotite-sillimanite residual enclave (JOY2-X4) was very close to our conductivity results for the run DS13 and DS14 gneiss samples in the lower-temperature and higher-temperature regions, respectively. The electrical conductivity of sample JOY2-X4 was slightly lower than the run DS12 gneiss sample. In addition, the electrical conductivity of natural metapelite (PP216) from Hashim et al. (2013) was close to the values of the run DS12 gneiss sample in the lower-temperature region, and the slope between logarithmic conductivities and reciprocal temperature for the PP216 metapelite was higher than the gneiss samples in the higher-temperature region.

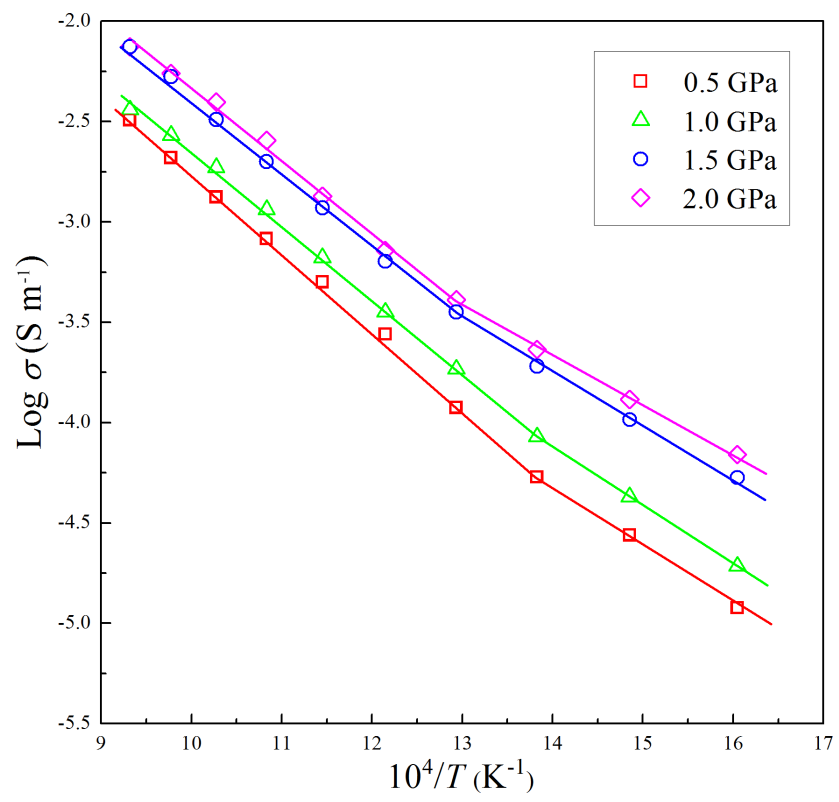

Figure 6. Logarithm of the electrical conductivities versus the reciprocal temperatures for run DS12 gneiss at 0.5-2.5 GPa and 623$1073 \mathrm{~K}$.

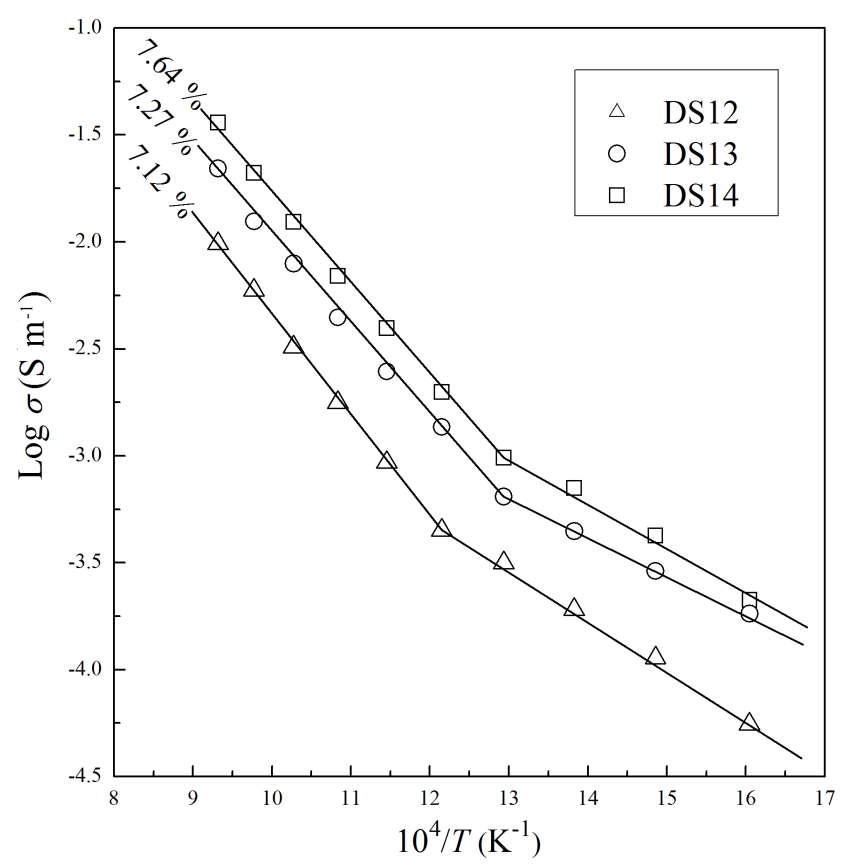

Figure 7. Logarithm of the electrical conductivities versus the reciprocal temperatures of the gneiss samples with various chemical compositions at $1.5 \mathrm{GPa}$ and $623-1073 \mathrm{~K}$.

\subsection{Conduction mechanism}

The logarithm of electrical conductivities and reciprocal temperatures showed linear relationships at the lower and higher temperature ranges, respectively. This implies that the dom- 
inant conduction mechanism for our gneiss samples in the lower temperature range is different from the higher temperature range. The mineral assemblage and chemical composition of gneiss samples are very complicated, and thus the conduction mechanisms for gneiss samples are difficult to determine. Feldspar, quartz and biotite are the dominant minerals in the gneiss samples. Previous studies have suggested that the conduction mechanism for feldspar minerals is ionic conduction and the charge carriers are $\mathrm{K}^{+}, \mathrm{Na}^{+}$and $\mathrm{Ca}^{2+}$ (Hu et al., 2013). The conduction mechanism for biotite has not been studied, whereas the charge carriers of phlogopite were proposed to be $\mathrm{F}^{-}$and $\mathrm{K}^{+}$(Li et al., 2016). For quartz, the conduction mechanism was impurity ionic conduction, and the dominant charge carriers migrate by moving the alkali ions in channels (Wang et al., 2010). Therefore, we deduced that the conduction mechanism for gneiss samples may be related to ions. The activation enthalpy is one crucial piece of evidence for the conduction mechanism of minerals and rocks (Dai et al., 2016). The activation enthalpies for gneiss samples are $0.35-0.58 \mathrm{eV}$ in the lower-temperature region and $0.77-0.87 \mathrm{eV}$ in the higher-temperature region (Table 3). Dai et al. (2014) studied the electrical conductivity of granite that had the same mineralogical assemblage as the gneiss samples. They proposed that the conduction mechanism at the lower temperature range was the impurity conduction owing to the low activation enthalpy $(0.5 \mathrm{eV})$, whereas the mechanism was ionic conduction with a high activation enthalpy $(1.0 \mathrm{eV})$ at the higher temperature range. The activation enthalpy for gneiss was close to the values for granite at the lower and higher temperature ranges. The activation enthalpies for albite and K-feldspar were 0.84 and $0.99 \mathrm{eV}$, respectively (Hu et al., 2013). With increasing pressure, the electrical conductivity of gneiss increased accordingly. The activation volumes for one gneiss sample (DS12) were -7.10 and $-2.69 \mathrm{~cm}^{3}$ mole $^{-1}$ in the low- and hightemperature regions, respectively. We can compare gneiss with the electrical conductivity of eclogite, another representative metamorphic rock. Recently, Dai et al. (2016) measured the electrical conductivity of dry eclogite and the negative activation volume for eclogite was $-2.51 \mathrm{~cm}^{3} \mathrm{~mole}^{-1}$ under $1.0-3.0 \mathrm{GPa}$ and $873-1173 \mathrm{~K}$. It was proposed that the main conduction mechanism for dry eclogite is intrinsic conduction (Dai et al., 2016). In addition, Fig. 7 shows that the increasing content of alkali and calcium ions significantly enhances the electrical conductivity of gneiss samples. Therefore, the impurity conduction (possible charge carriers: $\mathrm{K}^{+}$, $\mathrm{Na}^{+}, \mathrm{Ca}^{2+}$ and $\mathrm{H}^{+}$) and ionic conduction (possible charge carriers: $\mathrm{K}^{+}, \mathrm{Na}^{+}$and $\mathrm{Ca}^{2+}$ ) are suggested to be the conduction mechanisms at lower and higher temperature ranges, respectively.

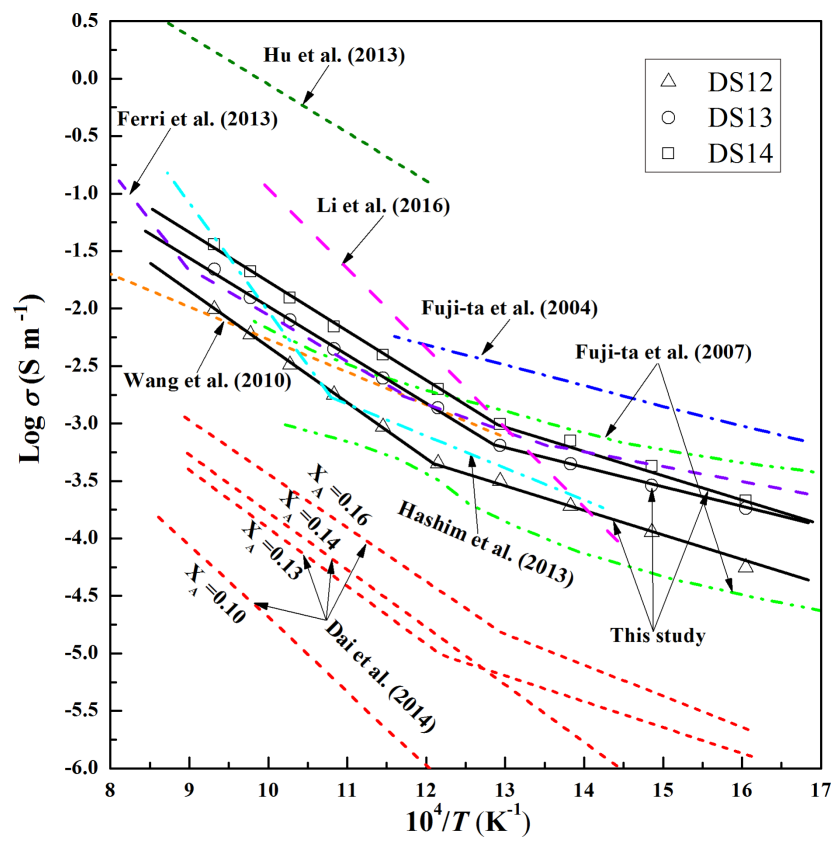

Figure 8. Comparisons of the electrical conductivities of the gneiss samples measured at $1.5 \mathrm{GPa}$ in this study and in previous studies. The dashed blue and green lines represent the electrical conductivities of granulite and gneiss at 1.0 GPa from Fuji-ta et al. (2004, 2007), respectively. The dashed orange line represents the electrical conductivity of quartz at 1.0 GPa from Wang et al. (2010), and the dashed dark green line represents the electrical conductivity of alkali feldspars at 1.0 GPa from $\mathrm{Hu}$ et al. (2013). The dashed sky blue line represents the electrical conductivity of natural PP216 metapelite at $0.3 \mathrm{GPa}$ from Hashim et al. (2013), and the dashed violet line represents the electrical conductivity of the residual JOY2$\mathrm{X} 4$ enclave at $0.3 \mathrm{GPa}$ from Ferri et al. (2013). The dashed red lines represent the electrical conductivity of granite at $0.5 \mathrm{GPa}$ from Dai et al. (2014), and the dashed pink line represents the electrical conductivity of phlogopite at 1.0 GPa from Li et al. (2016).

\subsection{Effect of chemical composition on electrical conductivity}

The influence of chemical composition $\left(\mathrm{Na}_{2} \mathrm{O}\right.$ $\left.+\mathrm{K}_{2} \mathrm{O}+\mathrm{CaO}\right)$ on the electrical conductivity of the gneiss samples was very significant, as shown in a previous study that the electrical conductivity of granite samples is closely related to the alkali and calcium ion content (Dai et al., 2014). The electrical conductivity of granite samples at high temperature and pressure can be fitted as a function of $\left(\mathrm{Na}_{2} \mathrm{O}+\mathrm{K}_{2} \mathrm{O}+\mathrm{CaO}\right) / \mathrm{SiO}_{2}$ (Dai et al., 2014). However, the electrical conductivity of gneiss samples does not regularly change with variations in $\left(\mathrm{Na}_{2} \mathrm{O}+\mathrm{K}_{2} \mathrm{O}+\mathrm{CaO}\right) / \mathrm{SiO}_{2}$. This may be due to the more complicated mineralogical assemblage and chemical composition of gneiss: for mineralogical assemblage, the biotite content of the gneiss sample is higher than granite. As for the chemical compositions, the contents of $\mathrm{SiO}_{2}$ for gneiss are lower than those of 


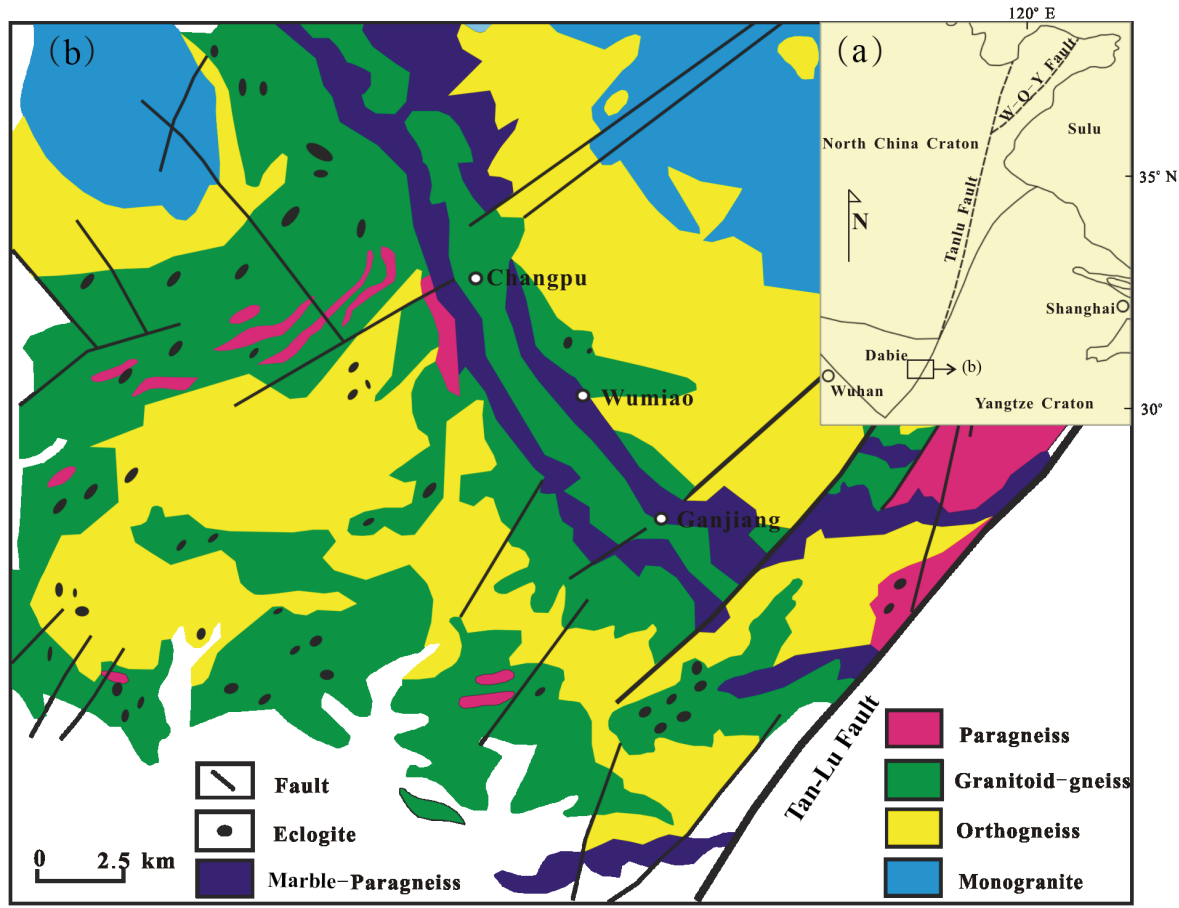

Figure 9. Geological sketch map of the Dabie-Sulu orogenic belt (a) and its correspondent lithological distribution diagram in the southern counterpart of the Dabie-Sulu region (b, modified after Xu et al., 2013; Liu et al., 2014).

granite samples, and the contents of the calc-alkali ions are approximate between gneiss and granite samples. $\mathrm{Hu}$ et al. (2013) demonstrated that the electrical conductivity of alkali feldspar significantly depends on the value of $\mathrm{Na} /(\mathrm{Na}+\mathrm{K})$. This suggests that the electrical conductivity of gneiss is affected by the total content of alkali and calcium ions, as well as the ratios between various ions.

\section{Geophysical implications}

As a typical metamorphic rock in the present research region, gneiss is widespread in the UHPM zone (Zheng et al., 2003; Liu et al., 2005; Hashim et al., 2013). The geological map of the Dabie-Sulu orogenic belt and its corresponding lithological distribution in the southern Dabie-Sulu region are displayed in Fig. 9. As one of the largest UHPM belts in the world for Dabie-Sulu orogen, gneiss is the outcropping rock directly in contact with eclogite and occupies up to $90 \%$ of the exposed metamorphic rock area. Therefore, the in situ laboratory-based electrical conductivity of gneiss at high temperature and pressure is very significant to interpret the conductivity structure in the Dabie-Sulu belt deep in the Earth's interior. The Dabie terrane is a major segment bounded by the Tan-Lu fault to the east and separated into a series of continuous zones by several largescale E-W-trending faults; the Sulu terrane is segmented into a number of blocks by several NE-SW-trending faults sub- parallel to the Tan-Lu fault (Zheng, 2008; Xu et al., 2013). The discovery of coesite and/or diamond inclusions in various types of rock (e.g., gneiss, eclogite, amphibolite, marble and jadeite quartzite) through the Dabie-Sulu orogen indicates that continental crust has been subducted at a depth of 80-200 km and subsequently exhumed to the Earth's surface. During subduction, dehydration reactions of some hydrous minerals (e.g., lawsonite, phengite and chlorite) and partial melting of other regional metamorphic rocks (e.g., gneiss and eclogite) occur at high temperature and pressure (Xu et al., 2013; Liu et al., 2014). Previous field MT results have found that high conductivity anomalies with magnitudes of $10^{-1} \mathrm{~S} \mathrm{~m}^{-1}$ are widely distributed at $10-20 \mathrm{~km}$ in the DabieSulu UHPM belt (Xiao et al., 2007). In addition, the slab-like high-velocity anomaly results have also confirmed a depth of $\geq 110 \mathrm{~km}$ for the uppermost mantle beneath the Dabie-Sulu orogen, which represents a remnant of the subducted Yangtze block after Triassic continent-continent collision (Xu et al., 2001). However, the origin and causal mechanisms of these high conductivity anomalies for the Dabie-Sulu UHPM belt are still unknown. Together with the two main constituent rocks (natural eclogite and granulite) in the UHPM belt, it is crucial to explore whether the gneiss electrical conductivity can be used to interpret the high conductivity anomalies distributed in the Dabie-Sulu tectonic belt. The relationship between temperature and depth in the Earth's stationary crust can be obtained by a numerical solution of the heat conduction equation (Selway et al., 2014): 


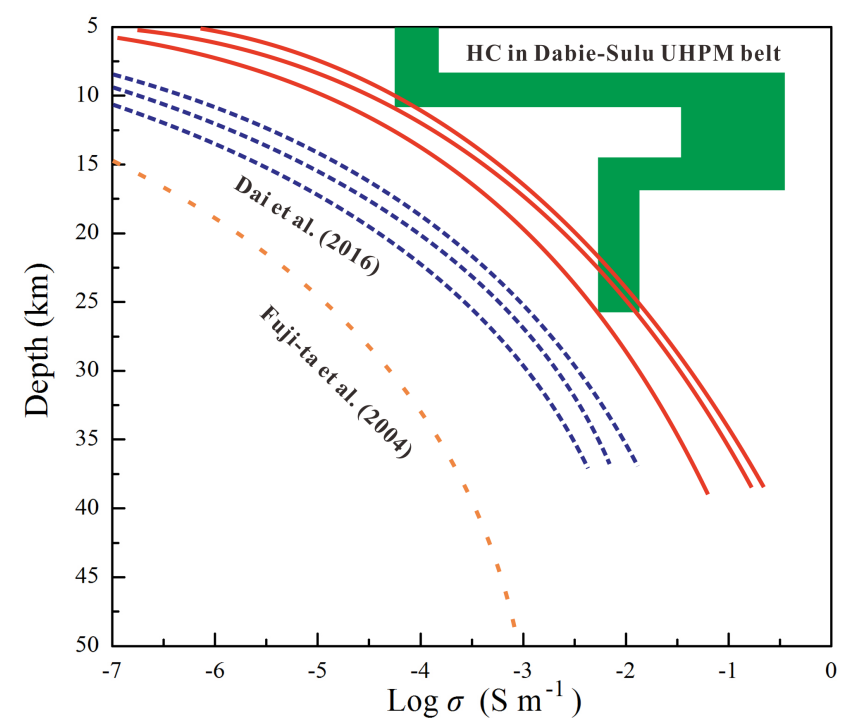

Figure 10. Laboratory-based conductivity-depth profiles constructed from data of the gneiss samples and the thermodynamic parameters; comparison with geophysically inferred field results from the Dabie-Sulu UHPM belt, China. The red solid lines represent the conductivity-depth profiles based on the conductivities of the samples described in Fig. 3 and based on a surface heat flow of $75 \mathrm{~mW} \mathrm{~m}^{-2}$ in the Dabie-Sulu UHPM belt. The dashed blue lines represent the conductivity-depth profiles based on the conductivities of eclogite, and the dashed brown line represents the conductivity-depth profiles based on the conductivities of granulite (Fuji-ta et al., 2004; Dai et al., 2016). The green region represents the MT data derived from a high conductivity anomaly in the Dabie-Sulu UHPM belt (Xiao et al., 2007; He et al., 2009).

$T=T_{0}+\left(\frac{Q}{k}\right) Z-\left(\frac{A_{0}}{2 k}\right) Z^{2}$,

where $T_{0}$ is the surface temperature $(\mathrm{K}), Q$ is the surface heat flow $\left(\mathrm{mW} \mathrm{m}^{-2}\right), Z$ is the lithosphere layer depth $(\mathrm{km}), k$ is thermal conductivity ( $\mathrm{W} \mathrm{mK}^{-1}$ ) and $A_{0}$ is the lithospheric radiogenic heat productivity $\left(\mu \mathrm{W} \mathrm{m}^{-3}\right)$. Based on previous studies, the corresponding thermal calculation parameters for the Dabie-Sulu orogen are $Q=75 \mathrm{~mW} \mathrm{~m}^{-2}$ (He et al., 2009), $A_{0}=0.31 \mu \mathrm{W} \mathrm{m}^{-3}$ and $k=2.6 \mathrm{~W} \mathrm{mK}^{-1}$ (Zhou et al., 2011).

Based on the heat conduction equation (Eq. 4) and thermal calculation parameters, the conductivity-temperature results of gneiss with various chemical compositions $\left(W_{A}=\mathrm{Na}_{2} \mathrm{O}+\mathrm{K}_{2} \mathrm{O}+\mathrm{CaO}=7.12,7.27\right.$ and $\left.7.64 \%\right)$ can be converted to a conductivity-depth profile for the Dabie-Sulu orogen (Fig. 10). A similar transformation was also conducted for granulite by Fuji-ta et al. (2004) and eclogite with different oxygen fugacity $(\mathrm{Cu}+\mathrm{CuO}, \mathrm{Ni}+\mathrm{NiO}$ and $\mathrm{Mo}+\mathrm{MoO}_{2}$ ) by Dai et al. (2016). Figure 10 makes clear that the high conductivity anomaly of $10^{-1.5}-10^{-0.5} \mathrm{~S} \mathrm{~m}^{-1}$ from the field MT results in the Dabie-Sulu UHPM belt oc- curs at $12-21 \mathrm{~km}$ compared with three dominant constituent rock conductivities of gneiss, granulite and eclogite in the region. Although our obtained electrical conductivity of gneiss with different chemical compositions is moderately higher than granulite and eclogite, it is not high enough to explain the high conductivity anomaly observed in field MT results in the Dabie-Sulu orogen. In other words, three dominant outcrops of metamorphic rocks, including gneiss, eclogite and granulite, are not substances that produce the high conductivity anomalies of the Dabie-Sulu orogen. However, the conductivity-depth profile for gneiss with various chemical compositions may provide an important constraint on the interpretation of field magnetotelluric conductivity results in the regional UHPM belt.

Aside from the chemical composition, other available alternative causes for high conductivity anomalies can be considered, such as water in nominally anhydrous minerals (Wang et al., 2006; Yang, 2011; Dai and Karato, 2009, 2014a), interconnected saline (or aqueous) fluids (Hashim et al., 2013; Shimojuku et al., 2014; Sinmyo and Keppler, 2017; Guo et al., 2015; Li et al., 2018), partial melting (Wei et al., 2001; Maumus et al., 2005; Gaillard et al., 2008; Ferri et al., 2013; Laumonier et al., 2015, 2017; Ghosh and Karki, 2017), interconnected secondary high conductivity phases (e.g., $\mathrm{FeS}, \mathrm{Fe}_{3} \mathrm{O}_{4}$; Jones et al., 2005; Bagdassarov et al., 2009; Padilha et al., 2015), dehydration of hydrous minerals (Wang et al., 2012, 2017; Manthilake et al., 2015, 2016; Hu et al., 2017; Sun et al., 2017a, b; Chen et al., 2018) and graphite films on mineral grain boundaries (Freund, 2003; Pous et al., 2004; Chen et al., 2017). In consideration of the similar formation conduction and geotectonic environments, the Himalaya-Tibetan orogenic system was compared with the Dabie-Sulu UHPM belt and explained high electrical conductivity anomalies. Previous evidence from magnetotelluric and elastic seismic velocity data in the southern Tibet and northwestern Himalaya zones has confirmed that the high conductivity and low-seismic-velocity anomalies are widespread at $10-25 \mathrm{~km}$ in the Himalaya-Tibetan orogenic system (Wei et al., 2001; Unsworth et al., 2005; Arora et al., 2007; Caldwell et al., 2009). Some studies have hypothesized that partial melting is the cause of the high conductivity anomalies in the Himalaya-Tibetan orogenic system (Wei et al., 2001; Gaillard et al., 2004; Hashim et al., 2013). Nevertheless other researchers think they are closely related with interconnected aqueous fluid (Makovsky and Klempere, 1999). As argued by Li et al. (2003), five possible hypotheses could explain the cause of the high conductivity anomalies in the INDEPTH magnetotelluric data of the southern Tibet mid-crust. The authors found that the high conductivity anomalies may be a result of interconnected melt and fluids. Recently, Naif et al. (2018) suggested that the high conductivity anomaly at $50-150 \mathrm{~km}$ can be explained by either a small amount of water stored in nominally anhydrous minerals or interconnected partial melts. In the present study, the electrical conductivity of gneiss with various chemical com- 
positions at high temperature and pressure cannot be used to interpret the high conductivity anomalies of the Dabie-Sulu UHPM belt. Therefore, we propose that it is possibly caused by interconnected fluids or melts that result in high conductivity anomalies for the Dabie-Sulu UHPM belt.

\section{Conclusions}

The electrical conductivity range of gneiss samples with various chemical compositions was about $10^{-5}-10^{-1} \mathrm{~S} \mathrm{~m}^{-1}$ at 623-1073 K and 0.5-2.0 GPa. Electrical conductivity of the gneiss samples significantly increased with temperature and weakly increased with pressure. The total alkaline ion content of $\mathrm{K}_{2} \mathrm{O}, \mathrm{Na}_{2} \mathrm{O}$ and $\mathrm{CaO}$ is a remarkable influence on the electrical conductivity of the gneiss samples. Based on various activation enthalpy ranges $(0.35-0.52$ and $0.76-0.87 \mathrm{eV})$ corresponding to higher- and lower-temperature regions at $1.5 \mathrm{GPa}$, two main conduction mechanisms are suggested to dominate the conductivity of gneiss: impurity conduction in the lower-temperature region and ionic conduction (charge carriers are $\mathrm{K}^{+}, \mathrm{Na}^{+}$and $\mathrm{Ca}^{2+}$ ) in the higher-temperature region. Because of the much lower conductivity of gneiss samples at high temperature and pressure, we confirmed that gneiss with various chemical compositions cannot cause the high conductivity anomalies in the Dabie-Sulu UHPM belt.

Data availability. The underlying data can be found in the Supplement.

\section{The Supplement related to this article is available online at https://doi.org/10.5194/se-9-233-2018-supplement.}

Competing interests. The authors declare that they have no conflict of interest.

Acknowledgements. We thank the editor, Ulrike Werban, and three anonymous reviewers for their very constructive comments and suggestions in the reviewing process, which helped us greatly in improving the paper. We appreciate Kara Bogus from the Edanz Group (www.edanzediting.com/ac) scientific editing company for support with English improvement on a previous version of the paper. This research was financially supported by the Strategic Priority Research Program (B) of the Chinese Academy of Sciences (XDB 18010401), the Key Research Program of Frontier Sciences of CAS (QYZDB-SSW-DQC009), the "135" Program of the Institute of Geochemistry of CAS, the Hundred Talents Program of CAS and the NSF of China (41474078, 41774099 and 41772042).

Edited by: Ulrike Werban

Reviewed by: Fabrice Gaillard and two anonymous referees

\section{References}

Arora, B. R., Unsworth, M. J., and Rawat, G.: Deep resistivity structure of the northwest Indian Himalaya and its tectonic implications, Geophys. Res. Lett., 34, L04307, https://doi.org/10.1029/2006GL029165, 2007.

Bagdassarov, N., Golabek, G. J., Solferion, G., and Schmidt, M. W.: Constraints on the Fe-S melt connectivity in mantle silicates from electrical impedance measurements, Phys. Earth Planet. In., 177, 139-146, 2009.

Caldwell, W. B., Klemperer, S. L., Rai, S. S., and Lawrence, J. F.: Partial melt in the upper-middle crust of northwest Himalaya are veiled by Rayleigh wave dispersion, Tectonophysics, 477, 58-65, 2009.

Chen, J. Y., Yang, X. S., and Chen, J. Y.: Experimental studies on the relationship between carbonaceous structure and electrical conductivity of the Longmenshan fault zone, Chinese J. Geophys., 60, 3475-3492, 2017

Chen, S. B., Guo, X. Z., Yoshino, T., Jin, Z. M., and Li, P.: Dehydration of phengite inferred by electrical conductivity measurements: Implication for the high conductivity anomalies relevant to the subduction zones, Geology, 46, 11-14, 2018.

Dai, L. D. and Karato, S. I.: High and highly anisotropic electrical conductivity of the asthenosphere due to hydrogen diffusion in olivine, Earth Planet. Sc. Lett., 408, 79-86, 2014a.

Dai, L. D. and Karato, S.: Influence of $\mathrm{FeO}$ and $\mathrm{H}$ on the electrical conductivity of olivine, Phys. Earth Planet. In., 237, 73-79, 2014b.

Dai, L. D. and Karato, S. I.: Electrical conductivity of wadsleyite at high temperatures and high pressures, Earth Planet. Sc. Lett., 287, 277-283, 2009.

Dai, L. D., Li, H. P., Hu, H. Y., and Shan S. M.: Experimental study of grain boundary electrical conductivities of dry synthetic peridotite under high-temperature, high-pressure, and different oxygen fugacity conditions, J. Geophys. Res., 113, B12211, https://doi.org/10.1029/2008JB005820, 2008.

Dai, L. D., Li, H. P., Hu, H. Y., Shan, S. M., Jiang, J. J., and Hui, K. S.: The effect of chemical composition and oxygen fugacity on the electrical conductivity of dry and hydrous garnet at high temperatures and pressures, Contrib. Mineral. Petr., 163, 689700, 2012.

Dai, L. D., Hu, H. Y., Li, H. P., Jiang, J. J., and Hui, K. S.: Influence of temperature, pressure, and chemical composition on the electrical conductivity of granite, Am. Mineral., 99, 1420-1428, 2014.

Dai, L. D., Hu, H. Y., Li, H. P., Wu, L., Hui, K. S., Jiang, J. J., and Sun, W. Q.: Influence of temperature, pressure, and oxygen fugacity on the electrical conductivity of dry eclogite, and geophysical implications, Geochem. Geophy. Geosy., 17, 2394 2407, 2016.

Ferri, F., Gibert, B., Violay, M., and Cesare, B.: Electrical conductivity in a partially molten crust from measurements on metasedimentary enclaves, Tectonophysics, 586, 84-94, 2013.

Freund, F.: On the electrical conductivity structure of the stable continental crust, J. Geodyn., 35, 353-388, 2003.

Fuji-ta, K., Katsura, T., and Tainosho, Y.: Electrical conductivity measurement of granulite under mid- to lower crustal pressuretemperature conditions, Geophys. J. Int., 157, 79-86, 2004.

Fuji-ta, K., Katsura, T., Matsuzaki, T., Ichiki, M., and Kobayashi, T.: Electrical conductivity measurement of gneiss under mid- 
to lower crustal $P-T$ conditions, Tectonophysics, 434, 93-101, 2007.

Gaillard, F., Scaillet, B., and Pichavant, M.: Evidence for presentday leucogranite pluton growth in Tibet, Geology, 32, 801-804, 2004.

Gaillard, F., Malki, M., Iacono-Marziano, G., Pichavant, M., and Scaillet, B.: Carbonatite melts and electrical conductivity in the asthenosphere, Science, 322, 1363-1365, 2008.

Ghosh, D. B. and Karki, B. B.: Transport properties of carbonated silicate melt at high pressure, Sci. Adv., 3, e1701840, https://doi.org/10.1126/sciadv.1701840, 2017.

Guo, X. Z., Yoshino, T., and Shimojuku, A.: Electrical conductivity of albite-(quartz)-water and albite-water- $\mathrm{NaCl}$ systems and its implication to the high conductivity anomalies in the continental crust, Earth Planet. Sc. Lett., 412, 1-9, 2015.

Hashim, L., Gaillard, F., Champallier, R., Breton, N. L., Arbaret, L., and Scaillet, B.: Experimental assessment of the relationships between electrical resistivity, crustal melting and strain localization beneath the Himalayan-Tibetan Belt, Earth Planet. Sc. Lett., 373, 20-30, 2013.

He, L., Hu, S., Yang, W., and Wang, J.: Radiogenic heat production in the lithosphere of Sulu ultrahigh-pressure metamorphic belt, Earth Planet. Sc. Lett., 277, 525-538, 2009.

Hu, H. Y., Li, H. P., Dai, L. D., Shan, S. M., and Zhu, C. M.: Electrical conductivity of albite at high temperatures and high pressures, Am. Mineral., 96, 1821-1827, 2011.

Hu, H. Y., Li, H. P., Dai, L. D., Shan, S. M., and Zhu, C. M.: Electrical conductivity of alkali feldspar solid solutions at high temperatures and high pressures, Phys. Chem. Miner., 40, 51-62, 2013.

Hu, H. Y., Dai, L. D., Li, H. P., Hui, K. S., and Sun, W. Q.: Influence of dehydration on the electrical conductivity of epidote and implications for high conductivity anomalies in subduction zones, J. Geophys. Res., 122, 2751-2762, 2017.

Hui, K. S., Zhang, H., Li, H. P., Dai, L. D., Hu, H. Y., Jiang, J. J., and Sun, W. Q.: Experimental study on the electrical conductivity of quartz andesite at high temperature and high pressure: evidence of grain boundary transport, Solid Earth, 6, 1037-1043, https://doi.org/10.5194/se-6-1037-2015, 2015.

Jones, A. G., Ledo, J., and Ferguson, I. J.: Electromagnetic images of the Trans-Hudson Orogen: The North American Central Plains anomaly revealed, Can. J. Earth Sci., 42, 457-478, 2005.

Laumonier, M., Gaillard, F., and Sifre, D.: The effect of pressure and water concentration on the electrical conductivity of dacitic melts: Implication for magnetotelluric imaging in subduction areas, Chem. Geol., 418, 66-76, 2015.

Laumonier, M., Gaillard, F., Muir, D., Blundy, J., and Unsworth, M.: Giant magmatic water reservoirs at mid-crustal depth inferred from electrical conductivity and the growth of the continental crust, Earth Planet. Sc. Lett., 457, 173-180, 2017.

Li, P., Guo, X. Z., Chen, S. B., Wang, C., Yang, J. L., and Zhou, X. F.: Electrical conductivity of the plagioclase-NaCl-water system and its implication for the high conductivity anomalies in the mid-lower crust of Tibet Plateau, Contrib. Mineral. Petr., 173, 16, https://doi.org/10.1007/s00410-018-1442-9, 2018.

Li, S., Unsworth, M., Booker, J., Wei, W., Tan, H., and Jones, A. G.: Partial melt or aqueous fluid in the mid-crust of Southern Tibet? Constraints from INDEPTH magnetotelluric data, Geophys. J. Int., 153, 289-304, 2003.
Li, Y., Yang, X. Z., Yu, J. H., and Cai, Y. F.: Unusually high electrical conductivity of phlogopite: The possible role of fluorine and geophysical implications, Contrib. Mineral. Petr., 171, 37, https://doi.org/10.1007/s00410-016-1252-x, 2016.

Liu, F. L., Xu, Z. Q., Yang, J. S., Zhang, Z. M., Xue, H. M., Meng, F. C., Li, T. F., and Cheng, S. Z.: Geochemical characteristics and genetic mechanism of orthgneiss and paragneiss in the depth intervals of 2000-3000 m from main drill hole of Chinese Continental Scientific Drilling Project, Acta Petrol. Sin., 21, 305-324, 2005.

Liu, P., Wu, Y., Liu, Q., Zhang, J. F., Zhang, L., and Jin, Z. M.: Partial melting of UHP calc-gneiss from the Dabie Mountains, Lithos, 192-195, 86-101, 2014.

Makovsky, Y. and Klemperer, S. L.: Measuring the seismic properties of Tibetan bright spots: Evidence for free aqueous fluids in the Tibetan middle crust, J. Geophys. Res., 104, 10795-10825, 1999.

Manthilake, G., Mookherjee, M., Bolfan-Casanova, N., and Andrault, D.: Electrical conductivity of lawsonite and dehydrating fluids at high pressures and temperatures, Geophys. Res. Lett., 42, 7398-7405, 2015.

Manthilake, G., Bolfan-Casanova, N., Novella, D., Mookherjee, M., and Andrault, D.: Dehydration of chlorite explains anomalously high electrical conductivity in the mantle wedges, Sci. Adv., 2, e1501631, https://doi.org/10.1126/sciadv.1501631, 2016.

Maumus, J., Bagdassarov, N., and Schmeling, H.: Electrical conductivity and partial melting of mafic rocks under pressure, Geochim. Cosmochim. Ac., 69, 4703-4718, 2005.

Naif, S.: An upper bound on the electrical conductivity of hydrated oceanic mantle at the onset of dehydration melting, Earth Planet. Sc. Lett., 482, 357-366, 2018.

Novella, D., Jacobsen, B., Weber, P. K., Tyburczy, J. A., Ryerson, F. J., and Du Frane, W. L.: Hydrogen self-diffusion in single crystal olivine and electrical conductivity of the earth's mantle, Sci. Rep., 7, 5344, https://doi.org/10.1038/s41598-017-05113-6, 2017.

Padilha, A. L., Vitorello, I., Antunes, C. E., and Padua, M. B.: Imaging three-dimensional crustal conductivity structures reflecting continental flood basalt effects hidden beneath thick intracratonic sedimentary basin, J. Geophys. Res., 120, 4702-4719, 2015.

Pape, L. P., Jones, A. G., Unsworth, M. J., Vozar, J., Wei, W. B., Jin, S., Ye, G. F., Jing, J. N., Dong, H., Zhang, L. T., and Xie, C. L.: Constraints on the evolution of crustal flow beneath Northern Tibet, Geochem. Geophy. Geosy., 12, 4237-4260, 2015.

Pous, J., Munoz, G., Heise, W., Melgarejo, J. C., and Quesada, C.: Electromagnetic imaging of Variscan crustal structures in SW Iberia: The role of interconnected graphite, Earth Planet. Sc. Lett., 217, 435-450, 2004.

Roberts, J. J. and Tyburczy, J. A.: Frequency dependent electrical properties of polycrystalline olivine compacts, J. Geophys. Res., 96, 16205-16222, 1991.

Saltas, V., Chatzistamou, V., Pentari, D., Paris, E., Triantis, D., Fitilis, I., and Vallianatos, F.: Complex electrical conductivity measurements of a KTB amphibolite sample at elevated temperatures, Mater. Chem. Phys., 139, 169-175, 2013.

Selway, K., Yi, J., and Karato, S.: Water content of the Tanzanian lithosphere from magnetotelluric data: Implications for cratonic growth and stability, Earth Planet. Sc. Lett., 388, 175-186, 2014. 
Shimojuku, A., Yoshino, T., and Yamazaki, D.: Electrical conductivity of brine-bearing quartzite at $1 \mathrm{GPa}$ : Implications for fluid content and salinity of the crust, Earth Planets Space, 66, 1-9, 2014.

Sinmyo, R. and Keppler, H.: Electrical conductivity of $\mathrm{NaCl}-$ bearing aqueous fluids to $600{ }^{\circ} \mathrm{C}$ and $1 \mathrm{GPa}$, Contrib. Mineral. Petr., 172, 4, https://doi.org/10.1007/s00410-016-1323-z, 2017.

Sun, W. Q., Dai, L. D., Li, H. P., Hu, H. Y., Wu, L., and Jiang, J. J.: Electrical conductivity of mudstone before and after dehydration at high temperatures and pressures, Am. Mineral., 102, 24502456, 2017a.

Sun, W. Q., Dai, L. D., Li, H. P., Hu, H. Y., Jiang, J. J., and Hui, K. S.: Effect of dehydration on the electrical conductivity of phyllite at high temperatures and pressures, Mineral. Petrol., 111, 853$863,2017 b$.

Unsworth, M. J., Jones, A. G., Wei, W., Marquis, G., Gokarn, S. G., and Spratt, J. E.: Project ININDEPTH Team: Crustal rheology of the Himalaya and southern Tibet inferred from magnetotelluric data, Nature, 438, 78-81, 2005.

Wang, D. J., Li, H. P., Matsuzaki, T., and Yoshino, T.: Anisotropy of synthetic quartz electrical conductivity at high pressure and temperature, J. Geophys. Res., 115, B09211, https://doi.org/10.1029/2009JB006695, 2010.

Wang, D. J., Mookherjee, M., Xu, Y. S., and Karato, S.: The effect of water on the electrical conductivity of olivine, Nature, 443, 977-980, 2006.

Wang, D. J., Guo, X. Y., Yu, Y. J., and Karato, S.: Electrical conductivity of amphibole-bearing rocks: Influence of dehydration, Contrib. Mineral. Petr., 164, 17-25, 2012.

Wang, D. J, Liu, X. W., Liu, T., Shen, K. W., Welch, D. O., and Li, B. S.: Constraints from the dehydration of antigorite on highconductivity anomalies in subduction zones, Sci. Rep., 7, 16893, https://doi.org/10.1038/s41598-017-16883-4, 2017.

Wannamaker, P. E., Caldwell, T. G., Jiracek, G. R., Maris, V., Hill, G. J., Ogawa, Y., Bibby, H. M., Bennie, S. L., and Heise, W.: Fluid and deformation regime of an advancing subduction system at Marlborough, New Zealand, Nature, 460, 733-736, 2009.

Wei, W., Unsworth, M., Jones, A. G., Booker, J., Tan, H., Nelson, K. D., Chen, L., Li, S., Solon, K., and Bedrosian, P.: Detection of wide spread fluids in the Tibetan crust by magnetotelluric studies, Science, 292, 716-718, 2001.
Xiao, Q. B., Zhao, G. Z., Zhan, Y., Chen, X. B., Tang, J., Wang, J. J., and Deng, Q. H.: A preliminary study on electrical structure and dynamics of the ultra-high pressure metamorphic belt beneath the Dabie Mountains, Chinese J. Geophys., 50, 710-721, 2007.

Xiao, Q. B., Cai, X. P., Liang, G. H., Xu, X. W., and Zhang, B. L.: Application of 2D magnetotelluric methods in a geological complex area, Xinjiang, China, J. Appl. Geophys., 75, 19-30, 2011.

Xu, H. J., Ye, K., Song, Y. R., Chen, Y., Zhang, J. F., Liu, Q., and Guo, S.: Prograde metamorphism, decompressional partial melting and subsequent melt fractional crystallization in the Weihai migmatitic gneisses, Sulu UHP terrane, eastern China, Chem. Geol., 341, 16-37, 2013.

Xu, P. F., Liu, F. T., Wang, Q. C., Cong, B. L., and Chen, H.: Slablike high velocity anomaly in the uppermost mantle beneath the Dabie-Sulu orogen, Geophys. Res. Lett., 28, 1847-1850, 2001.

Xu, Y. S., Shankland, T. J., and Duba, A. G.: Pressure effect on electrical conductivity of mantle olivine, Phys. Earth Planet. In., 118, 149-161, 2000.

Yang, X. Z.: Origin of high electrical conductivity in the lower continental crust: A review, Surv. Geophys., 32, 875-903, 2011.

Yang, X. Z., Keppler, H., McCammon, C., and Ni, H. W.: Electrical conductivity of orthopyroxene and plagioclase in the lower crust, Contrib. Mineral. Petr., 163, 33-48, 2012.

Zeng, S. H., Hu, X. Y., Li, J. H., Xu, S., Fang, H., and Cai, J. C.: Detection of the deep crustal structure of the Qiangtang terrane using magnetotelluric imaging, Tectonophysics, 661, 180-189, 2015.

Zheng, Y. F.: A perspective view on ultrahigh-pressure metamorphism and continental collision in the Dabie-Sulu orogenic belt, Chinese Sci. Bull., 53, 3081-3104, 2008.

Zheng, Y. F., Fu, B., Gong, B., and Li, L.: Stable isotope geochemistry of ultrahigh pressure metamorphic rocks from the DabieSulu orogen in China: Implications for geodynamics and fluid regime, Earth-Sci. Rev., 62, 105-161, 2003.

Zhou, W. G., Fan, D. W., Liu, Y. G., and Xie, H. S.: Measurements of wave velocity and electrical conductivity of an amphibolite from southwestern margin of the Tarim Basin at pressures to $1.0 \mathrm{GPa}$ and temperatures to $700^{\circ} \mathrm{C}$ : Comparison with field observations, Geophys. J. Int., 187, 1393-1404, 2011. 